\title{
Preface: Climate extremes and biogeochemical cycles in the terrestrial biosphere: impacts and feedbacks across scales
}

\author{
M. Bahn ${ }^{1}$, M. Reichstein ${ }^{2}$, K. Guan ${ }^{3}$, J. M. Moreno ${ }^{4}$, and C. Williams ${ }^{5}$ \\ ${ }^{1}$ Institute of Ecology, University of Innsbruck, Innsbruck, Austria \\ ${ }^{2}$ Max Planck Institute for Biogeochemistry, Jena, Germany \\ ${ }^{3}$ Department of Environmental Earth System Science, Stanford University, Stanford, CA 94025, USA \\ ${ }^{4}$ Departamento de Ciencias Ambientales, Universidad de Castilla-La Mancha, Campus Fábrica de Armas, \\ 45071, Toledo, Spain \\ ${ }^{5}$ Graduate School of Geography, Clark University, 950 Main Street, Worcester MA 01610, USA \\ Correspondence to: M. Bahn (michael.bahn@uibk.ac.at)
}

Climate projections suggest a significant increase in the frequency and severity of climate extremes (extreme weather or climate events), such as droughts, heatwaves, heavy precipitation events and storms (Seneviratne et al., 2012; Stocker et al., 2013). By impacting the biosphere and biogeochemical cycles, climate extremes may have profound implications for ecosystems, society and the climate system (Seneviratne et al., 2012; Reichstein et al., 2013). This special issue comprises a range of ecosystem-scale case studies, cross-system syntheses and continental-scale assessments of effects of climate extremes on biogeochemical cycles in the terrestrial biosphere. It has emerged from a global conference on the topic held in Seefeld, Austria, in 2013 (www. bgc-extremes2013.org; for major conclusions from the conference see Bahn et al., 2014, and Kayler et al., 2015) and related sessions at the American Geophysical Union Fall Meeting in 2013 and the European Geosciences Union General Assemblies in 2013 and 2014. The special issue complements another recent special issue of Biogeosciences entitled "Impacts of extreme climate events and disturbances on carbon dynamics“ (www.biogeosciences.net/special_issue124. html).

The ecosystem studies compiled here span from semiarid and Mediterranean forests to temperate grasslands and the Arctic tundra. Several articles report on effects of drought and temperature anomalies on processes ranging from ecosystem $\mathrm{CO}_{2}$ fluxes, productivity, carbon allocation and carbon use efficiency (Burri et al., 2014; Rambal et al., 2014; Ruehr et al., 2014; Zona et al. 2014) to plant water uptake (Hoekstra et al., 2014) and nitrogen cycling (Fuchslueger et al., 2014; Schuerings et al., 2014). A mod- elling study disentangles the role of physiological responses versus ecosystem properties and boundary layer feedbacks for explaining unexpectedly higher sensible heat fluxes over forest compared to grassland during heatwaves (van Heerwaarden and Teuling, 2014). Focussing on the effects of extreme rainfall events, Jung et al. (2014) analyse the export and reactivity of particulate and dissolved organic carbon in a headwater watershed under monsoon climate. While all these above papers report on direct concurrent effects of extreme events, some also point towards potential lagged effects (see Frank et al., 2015) of climate extremes on biogeochemical cycles, e.g. via carry-over effects from climate anomalies during previous years on tree growth (see combined model-data analysis by Rammig et al., 2015), differential responses of different species/functional types to climate extremes (Hoestra et al., 2014; Zona et al., 2014), implications of altered plant nitrogen uptake (Schuerings et al., 2014) for ecosystem carbon and nitrogen dynamics, or postwindthrow effects on microclimate and soil carbon turnover (Mayer et al., 2014). Two case studies highlight the consequences of indirect effects of climate extremes, which can facilitate the occurrence of fires or pest outbreaks. Fires have both immediate and slower follow-up effects on the terrestrial carbon balance (Li et al., 2014). A case study by Boot et al. (2015) shows that fire intensity may not necessarily affect the residence time of black carbon in litter. Another study on indirect effects of climate extremes analyses consequences of pine beetle outbreaks, whose impacts on growth and species composition can alter albedo and thus radiative forcing (Vanderhoof et al., 2013). 
Two synthesis studies explore effects of drought on important components of the carbon balance. Based on data synthesis and a modelling analysis across a range of biomes, Shi et al. (2014) conclude that responses of production and respiration differ in magnitude and are affected by different mechanisms which cause comparatively slower responses of respiration. Vicca et al. (2014) carried out a comprehensive synthesis of precipitation manipulation experiments, demonstrating that moisture responses of soil $\mathrm{CO}_{2}$ efflux from current climatic conditions cannot be used for predicting this important carbon flux under altered precipitation regimes and highlighting the need for well-comparable experiments.

Several articles of this special issue provide regional- to continental-scale assessments based on remote sensing and model analyses. They recognize, that for assessing effects of climate extremes on biogeochemical cycles, an approach is required which explicitly links extreme weather conditions to anomalous ecosystem behaviour (Smith, 2011; Reichstein et al., 2013). A global analysis based on this concept identifies water scarcity as the key driver of extreme reductions in ecosystem carbon uptake across continents, while the importance of fires, temperature extremes and intense precipitation events differs between continents (Zscheischler et al., 2014). On continents where water scarcity is a widespread climatic constraint, rainfall variability is an important driver of the spatial-temporal variability in land surface phenology (Australia; Broich et al., 2014), and intra-seasonal rainfall variability and especially rainy season length can profoundly affect biome distribution and productivity (Africa; Guan et al., 2014). In Europe, increased drought severity is expected to increase future risks for the net primary productivity and carbon sequestration, especially in the Mediterranean area (Rolinski et al., 2015). The risks increase mainly because of greater drought probability; ecosystem vulnerability will increase to a lesser extent (Van Oijen et al., 2014). During heatwaves, drought and temperature may have combined or separate effects on carbon fluxes, and their effects on plant respiration in different land cover types may differ (Bastos et al., 2014). An analysis of the 2003 European heatwave indicates that vegetation height is a reliable predictor of vegetation response, possibly because of its association with rooting depth and canopy heat capacity (Bevan et al., 2014).

Several overarching conclusions can be drawn from the articles compiled in this special issue, including the following:

- Due to differential responses of species and biogeochemical processes, climate extremes have the potential to alter carbon and nutrient dynamics, the energy balance and finally the ecosystem structure. This may have consequences for carbon sequestration, radiative forcing and thus the regional and global climate, and can result in lagged effects of climate extremes on biogeochemical cycles and their responses to climate changes.

- Global changes such as climate warming and landuse change can alter ecosystem responses to cli- mate extremes, leading to direct regional ecosystematmosphere feedbacks - for instance amplifying or moderating heatwaves. Thus future studies should make an effort to address their combined effects.

- The integration of experimental studies, long-term data sets, remote sensing and modelling is an important challenge and a promising avenue for achieving a more comprehensive understanding and improved projections of impacts and feedbacks of climate extremes on biogeochemical cycles across various temporal and spatial scales.

Acknowledgements. We thank Yiqi Luo and Peter van Bodegom for their editorial handling of one and two of the manuscripts, respectively, which were submitted as part of this special issue.

\section{References}

Bahn, M., Reichstein, M., Dukes, J. S., Smith, M. D., and McDowell, N.G.: Climate-biosphere interactions in a more extreme world, New Phytol., 202, 356-359, 2014.

Bastos, A., Gouveia, C. M., Trigo, R. M., and Running, S. W.: Analysing the spatio-temporal impacts of the 2003 and 2010 extreme heatwaves on plant productivity in Europe, Biogeosciences, 11, 3421-3435, doi:10.5194/bg-11-3421-2014, 2014.

Bevan, S. L., Los, S. O., and North, P. R. J.: Response of vegetation to the 2003 European drought was mitigated by height, Biogeosciences, 11, 2897-2908, doi:10.5194/bg-11-2897-2014, 2014.

Boot, C. M., Haddix, M., Paustian, K., and Cotrufo, M. F.: Distribution of black carbon in ponderosa pine forest floor and soils following the High Park wildfire, Biogeosciences, 12, 3029-3039, doi:10.5194/bg-12-3029-2015, 2015.

Broich, M., Huete, A., Tulbure, M. G., Ma, X., Xin, Q., Paget, M., Restrepo-Coupe, N., Davies, K., Devadas, R., and Held, A.: Land surface phenological response to decadal climate variability across Australia using satellite remote sensing, Biogeosciences, 11, 5181-5198, doi:10.5194/bg-11-5181-2014, 2014.

Burri, S., Sturm, P., Prechsl, U. E., Knohl, A., and Buchmann, N.: The impact of extreme summer drought on the short-term carbon coupling of photosynthesis to soil $\mathrm{CO}_{2}$ efflux in a temperate grassland, Biogeosciences, 11, 961-975, doi:10.5194/bg-11961-2014, 2014.

Frank, D., Reichstein, M., Bahn, M., Thonicke, K., Frank, D., Mahecha, M. D., Smith, P., van der Velde, M., Vicca, S., Babst, F., Beer, C., Buchmann, N., Canadell, J. G., Ciais, P., Cramer, W., Ibrom, A., Miglietta, F., Poulter, B., Rammig, A., Seneviratne, S. I., Walz, A., Wattenbach, M., Zavala, M. A., and Zscheischler, J.: Effects of climate extremes on the terrestrial carbon cycle: concepts, processes and potential future impacts, Glob. Change Biol., 21, 2861-2880, 2015.

Fuchslueger, L., Kastl, E.-M., Bauer, F., Kienzl, S., Hasibeder, R., Ladreiter-Knauss, T., Schmitt, M., Bahn, M., Schloter, M., Richter, A., and Szukics, U.: Effects of drought on nitrogen turnover and abundances of ammonia-oxidizers in mountain grassland, Biogeosciences, 11, 6003-6015, doi:10.5194/bg-116003-2014, 2014.

Guan, K., Good, S. P., Caylor, K. K., Sato, H., Wood, E. F., and Li, H.: Continental-scale impacts of intra-seasonal rainfall variabil- 
ity on simulated ecosystem responses in Africa, Biogeosciences, 11, 6939-6954, doi:10.5194/bg-11-6939-2014, 2014.

Hoekstra, N. J., Finn, J. A., Hofer, D., and Lüscher, A.: The effect of drought and interspecific interactions on depth of water uptake in deep- and shallow-rooting grassland species as determined by $\delta^{18} \mathrm{O}$ natural abundance, Biogeosciences, 11, 44934506, doi:10.5194/bg-11-4493-2014, 2014.

Jung, B.-J., Lee, J.-K., Kim, H., and Park, J.-H.: Export, biodegradation, and disinfection byproduct formation of dissolved and particulate organic carbon in a forested headwater stream during extreme rainfall events, Biogeosciences, 11, 6119-6129, doi:10.5194/bg-11-6119-2014, 2014.

Kayler, Z. E., De Boeck, H. J., Fatichi, S., Grünzweig, J. M., Merbold, L., Beier, C., McDowell, N., and Dukes, J. S.: Experiments to confront the environmental extremes of climate change, Front. Ecol. Env., 13, 219-225, 2015.

Li, F., Bond-Lamberty, B., and Levis, S.: Quantifying the role of fire in the Earth system - Part 2: Impact on the net carbon balance of global terrestrial ecosystems for the 20th century, Biogeosciences, 11, 1345-1360, doi:10.5194/bg-11-1345-2014, 2014.

Mayer, M., Matthews, B., Schindlbacher, A., and Katzensteiner, K.: Soil $\mathrm{CO}_{2}$ efflux from mountainous windthrow areas: dynamics over 12 years post-disturbance, Biogeosciences, 11, 6081-6093, doi:10.5194/bg-11-6081-2014, 2014.

Rambal, S., Lempereur, M., Limousin, J. M., Martin-StPaul, N. K., Ourcival, J. M., and Rodríguez-Calcerrada, J.: How drought severity constrains gross primary production(GPP) and its partitioning among carbon pools in a Quercus ilex coppice?, Biogeosciences, 11, 6855-6869, doi:10.5194/bg-11-6855-2014, 2014.

Rammig, A., Wiedermann, M., Donges, J. F., Babst, F., von Bloh, W., Frank, D., Thonicke, K., and Mahecha, M. D.: Coincidences of climate extremes and anomalous vegetation responses: comparing tree ring patterns to simulated productivity, Biogeosciences, 12, 373-385, doi:10.5194/bg-12-373-2015, 2015.

Reichstein, M., Bahn, M., Ciais, P., Frank, D., Mahecha, M. D., Seneviratne, S. I., Zscheischler, J., Beer, C., Buchmann, N., Frank, D. C., Papale, D., Rammig, A., Smith, P., Thonicke, K., van der Velde, M., Vicca, S., Walz, A., and Wattenbach, M.: Climate extremes and the carbon cycle, Nature, 500, 287-295, 2013.

Ruehr, N. K., Law, B. E., Quandt, D., and Williams, M.: Effects of heat and drought on carbon and water dynamics in a regenerating semi-arid pine forest: a combined experimental and modeling approach, Biogeosciences, 11, 4139-4156, doi:10.5194/bg11-4139-2014, 2014.

Rolinski, S., Rammig, A., Walz, A., von Bloh, W., van Oijen, M., and Thonicke, K.: A probabilistic risk assessment for the vulnerability of the European carbon cycle to weather extremes: the ecosystem perspective, Biogeosciences, 12, 18131831, doi:10.5194/bg-12-1813-2015, 2015.

Schuerings, J., Jentsch, A., Hammerl, V., Lenz, K., Henry, H. A. L., Malyshev, A. V., and Kreyling, J.: Increased winter soil temperature variability enhances nitrogen cycling and soil biotic activity in temperate heathland and grassland mesocosms, Biogeosciences, 11, 7051-7060, doi:10.5194/bg-11-7051-2014, 2014.

Seneviratne, S. I., Nicholls, N., Easterling, D., Goodess, C. M., Kanae, S., Kossin, J., Luo, Y., Marengo, J., McInnes, K., Rahimi, M., Reichstein, M., Sorteberg, A., Vera, C., and Zhang, X.: Changes in climate extremes and their impacts on the natural physical environment, edited by: Field, C. B., Barros, V., Stocker,
T. F., Qin, D., Dokken, D. J., Ebi, K. L., Mastrandrea, M. D., Mach, K. J., Plattner, G.-K., Allen, S. K., Tignor, M., and Midgley, P. M.: Managing the Risks of Extreme Events and Disasters to Advance Climate Change Adaptation (IPCC SREX Report), 109-230, 2012.

Shi, Z., Thomey, M. L., Mowll, W., Litvak, M., Brunsell, N. A., Collins, S. L., Pockman, W. T., Smith, M. D., Knapp, A. K., and Luo, Y.: Differential effects of extreme drought on production and respiration: synthesis and modeling analysis, Biogeosciences, 11, 621-633, doi:10.5194/bg-11-621-2014, 2014.

Smith, M. D.: An ecological perspective on extreme climatic events: a synthetic definition and framework to guide future research, J. Ecol., 99, 656-663, 2011.

Stocker, T. F., Qin, D. , Plattner, G. K., Tignor, M., Allen, S. K., Boschung, J., Nauels, A., Xia, Y., Bex, B., and Midgley, B. M. (Eds.): IPCC, 2013: Climate change 2013: the physical science basis. Contribution of working group I to the fifth assessment report of the intergovernmental panel on climate change, Cambridge University Press, Cambridge, United Kingdom and New York, NY, USA, 1535 pp., doi:10.1017/CBO9781107415324, 2013.

Vanderhoof, M., Williams, C. A., Shuai, Y., Jarvis, D., Kulakowski, D., and Masek, J.: Albedo-induced radiative forcing from mountain pine beetle outbreaks in forests, south-central Rocky Mountains: magnitude, persistence, and relation to outbreak severity, Biogeosciences, 11, 563-575, doi:10.5194/bg-11-563-2014, 2014.

van Heerwaarden, C. C. and Teuling, A. J.: Disentangling the response of forest and grassland energy exchange to heatwaves under idealized land-atmosphere coupling, Biogeosciences, 11, 6159-6171, doi:10.5194/bg-11-6159-2014, 2014.

Van Oijen, M., Balkovi, J., Beer, C., Cameron, D. R., Ciais, P., Cramer, W., Kato, T., Kuhnert, M., Martin, R., Myneni, R., Rammig, A., Rolinski, S., Soussana, J.-F., Thonicke, K., Van der Velde, M., and Xu, L.: Impact of droughts on the carbon cycle in European vegetation: a probabilistic risk analysis using six vegetation models, Biogeosciences, 11, 6357-6375, doi:10.5194/bg11-6357-2014, 2014.

Vicca, S., Bahn, M., Estiarte, M., van Loon, E. E., Vargas, R., Alberti, G., Ambus, P., Arain, M. A., Beier, C., Bentley, L. P., Borken, W., Buchmann, N., Collins, S. L., de Dato, G., Dukes, J. S., Escolar, C., Fay, P., Guidolotti, G., Hanson, P. J., Kahmen, A., Kröel-Dulay, G., Ladreiter-Knauss, T., Larsen, K. S., LelleiKovacs, E., Lebrija-Trejos, E., Maestre, F. T., Marhan, S., Marshall, M., Meir, P., Miao, Y., Muhr, J., Niklaus, P. A., Ogaya, R., Peñuelas, J., Poll, C., Rustad, L. E., Savage, K., Schindlbacher, A., Schmidt, I. K., Smith, A. R., Sotta, E. D., Suseela, V., Tietema, A., van Gestel, N., van Straaten, O., Wan, S., Weber, U., and Janssens, I. A.: Can current moisture responses predict soil $\mathrm{CO}_{2}$ efflux under altered precipitation regimes? A synthesis of manipulation experiments, Biogeosciences, 11, 2991-3013, doi:10.5194/bg-11-2991-2014, 2014.

Zona, D., Lipson, D. A., Richards, J. H., Phoenix, G. K., Liljedahl, A. K., Ueyama, M., Sturtevant, C. S., and Oechel, W. C.: Delayed responses of an Arctic ecosystem to an extreme summer: impacts on net ecosystem exchange and vegetation functioning, Biogeosciences, 11, 5877-5888, doi:10.5194/bg-11-5877-2014, 2014. 
Zscheischler, J., Reichstein, M., Harmeling, S., Rammig, A., Tomelleri, E., and Mahecha, M. D.: Extreme events in gross primary production: a characterization across continents, Biogeosciences, 11, 2909-2924, doi:10.5194/bg-11-2909-2014, 2014. 